\title{
Mapping Portfolio IT Investment by Perception Level Management and IT investments toward Organization Performance (Case study: BPR Mustika Utama Kolaka Southeast Sulawesi)
}

Nurfitria Ningsi ${ }^{1}$ and Apol Pribadi Subriadi ${ }^{1}$

\begin{abstract}
This research intended to give an overview on the micro banking to develop the concrete steps of IT infrastructure to facing the globalization of business. Previous studies showed that the differences in the perception of negative effect on long-term performance of the organization in this case the productivity paradox. Mapping IT Investment Portfolio as an approach to user orientation be appropriate alternative to achieving objective business success by offering a wide range of potential applications with objective of user needs. This study finding there are 15 potential applications that can be developed by Micro banking for 5 years later with specific application indeed to reflecting all levels of management needs.
\end{abstract}

Keywords- Perception Level Management, Mapping Portfolio IT Investment, Performance Organization.

\section{INTRODUCTION}

Perception as a primary key to develop the business performance. seen the success of IT implementation not only due to the success of IT but also as the executor of IT management that support large role bussiness success. IT investment is a unique phenomenon for the development of science, especially for academics and practitioners in the field of social sciences and management. Where in previous years there were Pros and Cons of looking at IT investments. Cron \& Sobol (1983), Banker \& Kauffmann (1988), Alphard \& Kim (1990) approved if IT investments have negative effect for short-term organizational performance. Dan Remenyi (1999) in the IT Investment making a Bussiness Case, explaining if the evaluation of investment particularly in the field of IT that still have little attract a subset issues that can't evaluate of IT. investments considered as a process assessing the overall value of each piece of IT that is expected to increase profits of the company and was able to give feedback ratings that are useful for decision-making. Hannu Kivijarvi \& Timo Sarinen (1995), Strassmann (2003) regarding if IT investment is not always associated with short-term financial advantage, where IT investment is defined as the union of IT maturity level associated with improved firm performance. Based

\footnotetext{
${ }^{1}$ Nurfitria Ningsi and Apol Pribadi Subriadi are Departement of Information System, Institut Teknologi Sepuluh Nopember, Surabaya, Indonesia. E-mail: nurfitrianingsi35@gmail.com; apolpribadi@gmail.com.
}

on review of IT investment operations BPR Mustika Utama (Micro banking) not maximized apart due to limited funding, lack of understanding of IT investments lead to the circulation of information is not unidirectional and is certainly greatly affect the productivity of the personnel in the organization level. La Bala (2015)

Differences in perception is not a new phenomenon in the organization's business activities, Setyorini,D (2005) explains that there are at least 10 differences variables in perception between Lower Management and Top Management in the planning process of information systems that comprise, among others: the quality of the planning process, the time span planning, resource planning, business integration with information systems, the quality of mechanisms support, the involvement of Top Management, the involvement of users, the sources of the information system, the effectiveness of planning, information systems performance, and contribution information system. Tallon et.al., (2001) consider that there are differences in business value perceived by the Top Management in contrast to the perceived Lower Management in line with the findings of Puspitasari (2009) differences in perception Lower Management and Top Management occurs in the value chain include: planning and support, relationships with suppliers, operations and products, sales and marketing support, as well as relationships with Customers.

This research is important because during the Lower Management is still becoming underestimated role, whereas the directly involved in conducting operational planning system. So the conclusion of this paper is the strategic planning of IS / IT right through elections approach mapping investment portfolio we can understand the role of Level Management organization as well as its contribution in IT investments so as to illustrate the achievement of IT investments thorough in order to create a conducive environment for business performance improvement organization. Considering that during this time in the form of strategic planning major IT investments BPR mustika Kolaka still using traditional technology.

\section{METHOD}

This study using Mix method approach with conducting interviews and questionnaires to 24 informants for the objects in meticulous, with a total of 14 informants who managed to respond and provide information that researchers need. Taking into specification phase of the study are as follows: 


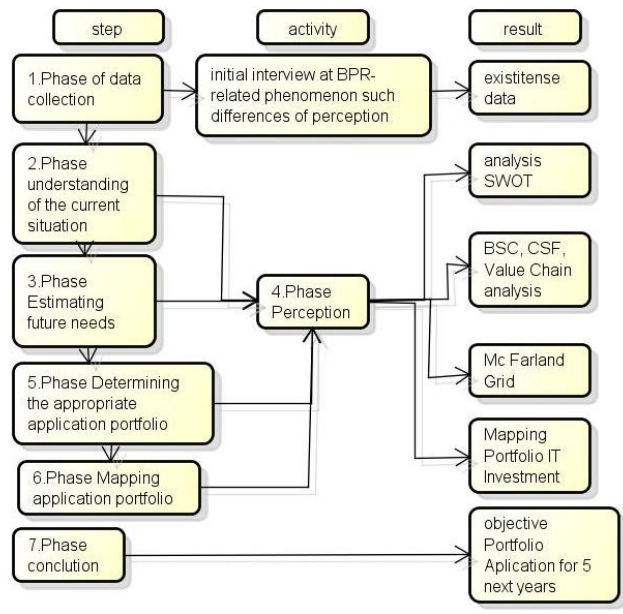

Figure 1. Swot Analysis

\section{RESULTS AND DISCUSSION}

From SWOT analysis findings based on Perception of Level management can be seen by the following graph:

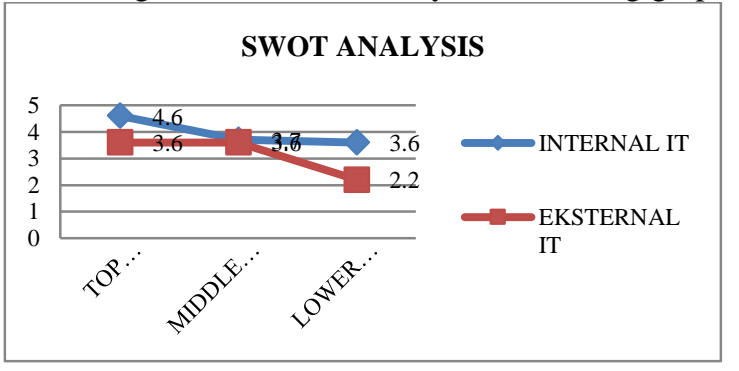

Figure 2. Swot Analysis

These findings support that micro banking adopting business expansion strategy. because each level management complement each other well in maximizing their power through the use of FISA applications, the used of tools cristal report as well as the availability of adequate IT infrastructure as microscale bank. Referring research of Arif Afandi et. al., (2010), Khakim Ghozali \& Febby Artwodini (2011), regarding perception of potential applications by Top, Middle and Lower Management:

$$
\text { TABLE } 1 .
$$

SWOT APLICATION POTENTIAL

\begin{tabular}{ll}
\hline \hline \multicolumn{1}{c}{ Aplication Potencial } \\
\hline 1. \\
2. Wertal Aplication $T M L$ \\
3. Costumer Based Information system (CBIS) $M L$ \\
4. Complain Information System (CIS) $M L$ \\
5. Procurement Information System (PIS) $T$ \\
\hline \hline
\end{tabular}

This analysist finding if there are 5 potential application which efective to support current strategic bussiness.

\section{A. The Findings Of Future Needs Analysis}

1) IT Balanced Scorecard Analysis

Table perception of IT Balanced Scorecard according to each level of management can be presented simply as follows:

TABLE 2.

BALANCED SCORECARD ANALYSIS

\begin{tabular}{ccccc}
\hline \hline Level & Cco & Cor & Ope & Fur \\
\hline Top Management & 0,7 & 0,72 & 0,742 & 0,8 \\
\hline Middle Management & 0,64 & 0,571 & 0,714 & 0,657 \\
\hline Lower Management & 0,62 & 0,628 & 0,6 & 0,65 \\
\hline \hline
\end{tabular}

Can be presented simply in the following graph:



Figure 3. IT Balanced Scorecard

As for potential applications that can be developed BPR in realizing its business expansion are as follows:

TABLE 3.

APLiCATION POTENTIAL OF IT BALANCED SCORECARD Aplication Potencial

1) Workflow aplication (WA)

2) Website BPR

3) Marketing Information system (MIS) $T$

4) Eksekutif Information System (EIS) (T)

5) Complain Information System (CIS) L

6) Knowledge Management system $M L$

7) Sistem Otomasi Perkantoran (OAS) $T M L$

8) Desicion Support system (DSS) TM

9) Human Resource Information system (HRIS) payroll and attendance module $M L$

10) Equipment Monitoring Information system (EMIS) $M L$

11) Management Information System (MIS) $M$

12) Group Support System (GSS) $L$

13) Human Resource Information system (HRIS) module HR $L$

14) Finance and Human Resource Information system (module back up data) $M L$

15) Procurement Information System (PIS) $M$

16) Costumer Based Information system (CBIS)

This analysist finding if there are 16 potential application that can provide and support bussiness strategic in the future.

2) Analysis Critical Success factor

Supported of level management is essential to ensure business success. Colquit, Le Pine and Wesson (2011) in Wibowo (2014) states the importance of behavioral orientation of the organization in achieving organizational effectiveness.

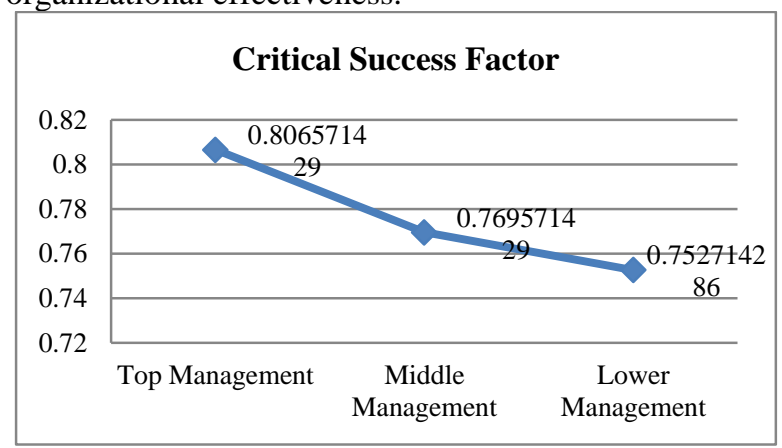

Figure 4. Critical Success Factor

Here the support proportion of perception of level management. With potential applications that can be built is as follows: 
TABLE 4.

CRITICAL SUCCESS FACTOR APLICATION POTENTIAL Aplication Potencial

1) Workflow Aplication (WA)

2) Website BPR

3) Marketing Information system (MIS) $T$

4) Eksekutif Information System (EIS) $T$

5) Complain Information System (CIS) $L$

6) Knowledge Management system $M L$

7) Office Automation System (OAS) $T M L$

8) Desicion Support system (DSS) $T M$

9) Human Resource Information system (HRIS) payroll and attendance module $M L$

10) Human Resources Information System (HRIS) satisfaction employee module $M L$

11) Equipment Monitoring Information system (EMIS) $M L$

12) Management Information System (MIS) $M$

13) Group Support System (GSS) $L$

14) Human Resource Information system (HRIS) modul HR $M L$

15) Finance and Human Resource Information system (module back up data) $M L$

16) Financial Integrated System Applications (FISA) $M L$

17) Costumer Based Information system (CBIS) $M L$

18) Employee information system (EIS) reward and punishment $M L$

19) Resources planing information system (RPIS) $T M$

This analysist finding there are 19 potentia application to support critical success factor to provide the organization

3) Value Chain

Following the acquisition value chain descriptions of each level management With potential applications supported is:

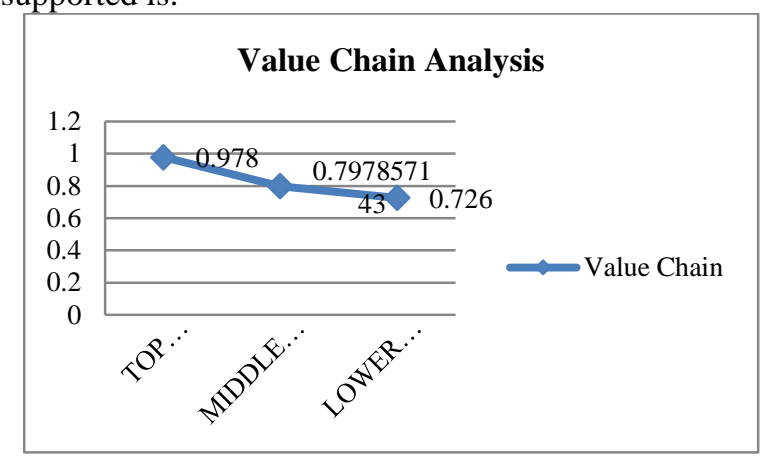

Figure 5. Value Chain Analysis

With specifics aplication potention of each leve management:

TABLE 5.

VALUE CHAIN APLICATION POTENTION

$$
\text { Aplication potential }
$$

. Resources Planning Information System (RPIS) TM

2. Executive Information System (EIS) $T$

3. Knowledge Management information system (KMIS) $T M L$

4. Website BPR TML

5. Marketing information system (MKIS) $T$

6. Management Information system (MIS) $M$

7. Human Resources Information System (HRIS) Job Satisfaction Module ML

8. Human Resources Information System (HRIS) payroll and attendance module $M L$

9. Work Flow $M L$

10. Employee information system (EIS) reward and punishment $M L$

11. Complain Information System (CIS) $L$

12. Procurement Information System (PIS) $M L$

13. Group Support System (GSS) $M L$

14. Financial Integrated System Application (FISA) $M L$

15. Costumer Based Information system (CBIS) $M L$

16. Human Resource Information system (HRIS) Satisfaction employee module $T M L$
Based on activity analysist we finding at least 16 potential application to provide all management ability.

B. The Findings Classification Mc Farland Grid

Application portfolio classification by determining the quadrant of each application based on the criteria Mc Farland

TABLE 6.

MC FARLAND GRID APLICATION POTENTIAL

\begin{tabular}{|c|c|c|}
\hline \begin{tabular}{ll} 
& \multicolumn{1}{c}{ Strategic } \\
1. & $\begin{array}{l}\text { Executive Information } \\
\text { System (EIS) }\end{array}$ \\
2. & $\begin{array}{l}\text { Marketing Information } \\
\text { System (MKIS) }\end{array}$
\end{tabular} & \multicolumn{2}{|c|}{ "High Potential } \\
\hline \multirow{4}{*}{$\begin{array}{ll}\text { 1. Executive Information } \\
\text { System (EIS) } \\
\text { 2. Marketing Information } \\
\text { System (MKIS) }\end{array}$} & 1. Website BP & \\
\hline & 2. Resources $P$ & \\
\hline & $\begin{array}{l}\text { Information } \\
\text { (RPIS) }\end{array}$ & \\
\hline & $\begin{array}{l}\text { 3. Costumer } \\
\text { Information } \\
\text { (CBIS) }\end{array}$ & $\begin{array}{l}\text { Based } \\
\text { system }\end{array}$ \\
\hline
\end{tabular}

\begin{tabular}{|c|c|c|}
\hline \multirow{4}{*}{$\begin{array}{l}1 . \\
2 .\end{array}$} & Work Flow Aplication & \multirow{2}{*}{$\begin{array}{l}\text { 1. Knowledge Management } \\
\text { information system (KMIS) }\end{array}$} \\
\hline & Resource & \\
\hline & Information & 2. Employee information \\
\hline & $\begin{array}{l}\text { (HRIS) payroll and } \\
\text { attendance module }\end{array}$ & $\begin{array}{l}\text { system (EIS) reward and } \\
\text { punishment }\end{array}$ \\
\hline 3. & Complain Information & Group Support System (GSS) \\
\hline & System (CIS) & Human Resources \\
\hline 4. & Equipment Monitoring & Information System (HRIS) \\
\hline & Information system & faction employee module \\
\hline & (EMIS) & Procurement \\
\hline 5. & Management & System (PIS) \\
\hline
\end{tabular}

Information System (MIS)

6. Finansial Integrated System Application (FISA)

Results showing if there 16 potential applications can be developed BPR to improve performance level management.

C. The Findings Of Mapping Portfolio It Investment

In this phase Mapping Investment Portfolio have steps are as following by:

1) Mapping the application potential into interval scale of system maps Position

In step one clasificate the data into interval scale of where data qualify from $(-15)$ to $(0,0)$ that difined as preferred aplication and from $(0,1)$ to $(+15)$ difined as proposed application to future requirement of organization. That simply present at the table bellow:

$$
\text { TABLE } 7 .
$$

INTERVAL SCALE OF MAPPING PROCESS

\begin{tabular}{cc}
\hline \hline Interval & Information \\
\hline$(-15)-(0,0)$ & Difined as prefered apps \\
$(0,1)-(+15)$ & Difined as proposed apps
\end{tabular}

After defining application scale, then mapping the domain indicator into mapping portfolio, and can present in the picture bellow:

a. from this figure we can conclude that there 5 potential application which support IT investment, where as RPIS as application which support decrease of IT cost, and PIS is application which intersecting IT cost and IT benefit that defining if this application can give support more than organization needs, and there are 3 application which intersecting IT benefit and IT Risk that showing if this application can influence uncertainty risk in future like HR problem and Changes of costumer behavior.

b. After known about portfolio IT investment now we should comparing existence of performance 
organization, that can be present in this picture bellow:

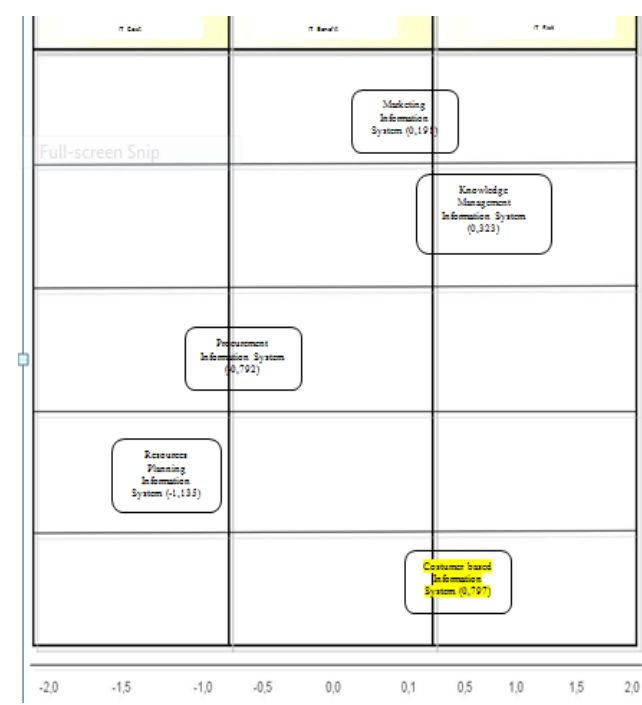

Figure 6. It Investment Map Application

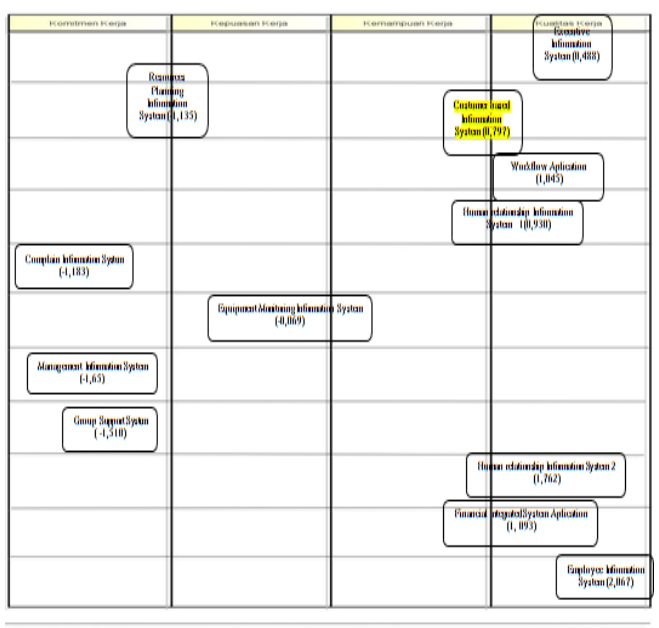

Figure 7. Mapping Perfomance organization potential application 2) Evaluating existence of application potential related with key criteria

After mapping the application then evaluating the potential application and find gap of system with using key criteria.

TABLE 8.

KEY CRITERIA OF POTENTIAL APPLICATION

\begin{tabular}{|c|c|c|c|c|}
\hline Application & & User & & Key Variabel \\
\hline \multirow{2}{*}{ EIS } & \multirow{2}{*}{ Top } & & & $\mathrm{CSF}$ \\
\hline & & & & Forecasting \\
\hline MKIS & Top & & & Promotion \\
\hline WEB & Top & & & Bussiness Profile \\
\hline PIS & Top & & & Management Control \\
\hline RPIS & Top & & & Budgeting \\
\hline CBIS & Top & Middle & Lower & Promotion Design \\
\hline WF & & Middle & Lower & Job Description \\
\hline HRIS1 & & Middle & Lower & Employee Adm \\
\hline CIS & & & Lower & $\begin{array}{l}\text { Complain } \\
\text { Management }\end{array}$ \\
\hline EMIS & & Middle & Lower & $\begin{array}{l}\text { Job Satisfaction } \\
\text { Indicator }\end{array}$ \\
\hline
\end{tabular}

\begin{tabular}{rrll} 
MIS & Middle & Job Control \\
\hline KMIS & Middle & Lower & Training Plan \\
\hline GSS & Middle & Lower & $\begin{array}{l}\text { Job Satisfaction } \\
\text { Indicator }\end{array}$ \\
\hline HRIS2 & Middle & Lower & Absensi \\
\hline FISA & Middle & Lower & Finacial Module \\
\hline \hline Information: & & \\
Top & & \\
Middle & $=$ Middle Management & \\
Lower = Lower Management & \\
3) Planning control system & \\
Planning control was performed using estimates of the
\end{tabular}

Planning control was performed using estimates of the economic value of the application itself, which in this study is used to predict the IRR metrics application lifecycle in 5 years later.

The findings showed that seven applications with a positive score is less call for support for the increase in its perception (level management) but otherwise Application above represent a negative influence means that the application is located at a point between 0.0 to 2.0 indicates less than the maximum representation in support of its effectiveness (management level) in the map application portfolio. On the other side of the app Resources Planning Information System with a score of $(-1.13)$ and application Complain Information System with a score of -1.183 which is in a position between (1.0) to $(-1.5)$.

Equipment Monitoring Information System Application with a score of $(-0.069)$ which stood at between 0.0 to $(-0,5)$. Application Management Information System with a score of (-1.165) and applications Group Support System with a score of ($1,5) 10$ is in a position between $(-1.0)$ to $(-1.5)$, which means that the five applications with negative scores are giving great support to improve the effectiveness of organizational performance period the next, or it can be concluded that the application with a negative score is not interpreted as the effect of a really negative but the condition is defined as a maximum of effectiveness in the application of IT investment portfolio map.

In line with Peter findings (1989) there are three dimensional of IT investments that include: 1) Decrease IT Costs; 2) Increased Benefits IT; and 3) Minimize the Risk. Where the dimensions of IT investment is seen as a dimension of long-term investment, with a decrease in the cost of IT in the extreme will Reduce the risk of long-term IT. Improved combination of several IT benefits would suppress an increased risk of long-term IT. Increased IT benefits will gradually lower the longterm IT costs. Investment Dimensions easily measured in monetary measures, especially the real benefits (tangible). Dimensions of IT investments are combined in creating value for the business, to produce products and services, and to solve business problems.

Dimensions of IT investment is very important to know the level of satisfaction of management level to understanding the intangible benefits of IT investments are difficult measured. Based on criteria with scale of 2 to +2 in order dimensions of the investment can be improved, where investment is productive and more profitable will reduce the cost of IT is described to be in a scale of 0 to $(-2)$ and a poor investment products will 
August $2^{\text {nd }}$ 2016, Postgraduate Program Institut Teknologi Sepuluh Nopember, Surabaya, Indonesia

increase the risk of IT are in a scale of 0 to +2 in this case the investment is not productive and should be noted as a negative influence and does not represent a good investment for use in future investment map.

Each category of the dimensions of the IT investments are in a scale of 0.5 to +2 , it mean highest risk offering higher the benefit, the risk of the business in the future will also in line with business growth. Mapping standard connecting dimensions of IT investment on the $x$ axis and the dimensions of organizational performance on the $y$ axis.

Based on information from the 16 applications that have been subsequently converted into map intact so as to produce a perfect piece of the second axis applications both the $\mathrm{x}$-axis and $\mathrm{y}$-axis. Here Mapping IT application portfolio investment:

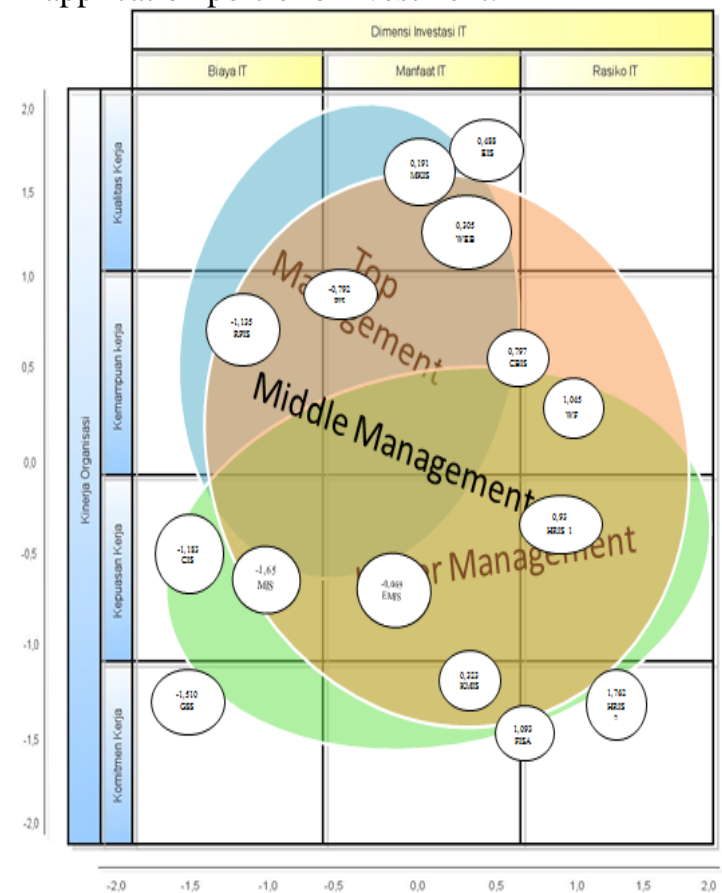

Figure 8. Mapping Portfolio IT Investment

Where the Circle of user perception (level management) made with cirle shape so that can relating the intersection between each application until showing big map and give complete description of one and other application. Above the description concluded in line with of Peter (1990) findings if This study supports that map portfolio application is can reflect user's perception regarding the use of an ideal application for the development of business in the future. In addition this study not only to develop IT investments future through quantitative assessment on Dimension investment IT but also examines the qualitative elements that are intangible elements that are still ignored in previous research

\section{CONCLUSION}

Regression analysis showed that the influences of the positive and significant correlation between Perception Level Management and IT investment this can be seen from the value of the $\mathrm{t}$-test $(\mathrm{t}$ stat $)=5.903>\mathrm{t}$-table $=$ 2.179 .

Based on Map Portfolio Applications obtained the information that there were 15 type applications that may be developed by BPR Mustika Utama among others: Framework (WA), Website RB, Marketing
Information System (MIS), Executive Information System (EIS), Complain Information System (CIS ), Knowledge Management system, Automation Systems Office (OAS), desicion support system (DSS), Human Resource information System (HRIS) module attendance and payroll, Equipment Monitoring information System (EMIS), Management information System (MIS), information system support groups (GSS), Human Resource Information system (HRIS) module HR, Finance and Human Resource Information system (module back up data), Procurement Information system (PIS), and Customer Based Information system (CBIS).

\section{CONCLUSION}

This research is the development of Peter Finding (1990), who developed the mapping investment portfolio of IT to identify the benefits of IT in which the research develops different treatments on some qualitative variable such as the quality of work, job satisfaction, work ability and commitment to work so as to produce variations in the more developed, However, the long-term needs consider regarding of the potential applications that will require follow-up by adoption due to the fact there are some features of applications that have been provide the same tools so that if the deposits would allow the emergence of multiple applications that ultimately even be an act of futility.

\section{FUTURE RESEARCH}

For future research can developed with the next phase where as the evaluation phase to assess the achievement of IT adoption and Maintance phase from previous IT portfolio so that the application is applied year next year is the objective with the needs of all users..

\section{REFERENCES}

[1] Afandy Arif, et.al., 2010. Pembuatan Portofolio Aplikasi PT.XYZ Unit Otonom ABC. Tugas Akhir

[2] Bala La, 2015. Bank mustika Utama kolaka. Kolaka Sulawesi Tenggara. 93517

[3] Bannister, F and Remenyi, "Act of Faith: Instinct, Value and IT Investment Decision”, J. Inf. Technol., vol 15, no. 3, pp 231241,2000

[4] Ghozali. Khakim., 2009. Pembuatan Portofolio Aplikasi di Dinas XYZ. Surabaya. Thesis tidak diterbitkan.

[5] Kauffmann et. al., 1989. An Evaluation Framework for Research on the Performance Effects of Information Technology Investment. Working Paper IS-89-83. Newyork. USA

[6] Kivarji Hannu et.al., 1995. Investment in Information System and Financial Performance of the Firm, Information and Management 28. Helsinki, Finland (hal 143-163)

[7] Pajo Karl, et.al., The Impact of Individual Goal Orientation and Perception of Support for Employee Development on Work Related Outcomes. Newzealand

[8] Peters, Glen. 1988. Evaluating Your Computer Investment Strategy. Journal of Information Technology. September 1988 pp $123-134$.

[9] Peters, Glen. 1990. Beyond Strategy : Benefit Identification and Management of Specific IT Investment. Journal of Information Technology. 1990. Vol. 5 pp 205 - 214.

[10] [Puspitasari, Evie. 2009. Nilai Bisnis IT Perceptual Menuru Perspektif Upper Management dan Lower Management : Sebuah Pendekatan Berorientasi Proses. Research Day of Econimic Faculty Padjadjaran University. Bandung. (hal $1-8$ )

[11] Rai Arun, et.al., 1997. Technology Investment and Bussiness Performance. Communication of the ACM vol 40 No.7. Carbondale. (hal 89 - 97) 
[12] Remenyi Dan, et.al., 1999. Instinct and Value in IT Investment Decisions. Wolverhampton Business School Management Research Centre. Gothenberg (hal 2 - 14)

[13] Rushinek Avi, Sara F. Rushinek, Joel Stutz. Relationship of Computer Users performance to their Atitudes toward interactive Software. J.Education Technology Systems Vol. 13(4), Miami USA

[14] Setyorini Dyah. 2005. Persepsi Upper Manager dan Lower Manager terhadap Perencanaan Sistem Informasi pada Lingkungan Sistem Informasi Strategik dan Turnaround. Jurnal Pendidikan Akuntansi Indonesia vol.4 no.2 (hal 1-13)

[15] Skok Walter. 2001. Diagnosing Information System Success : Importance - Performance Maps in the Health Club Industry. Journal Information Management 38.(hal 409 - 419) Kingston.

[16] Sneiderjan Marry et.al., 2004. Information Technology Investment Decision Making Methodology. Hal (3-345)

[17] Strassmann, P,. " Information Payoff ", Free Press, Newyork, 2003

[18] Tallon P, Paul., 2001. Executives Perceptions of the Bussiness Value of Information Technology : A process - Oriented Approach. Working Paper - 148. California. USA (hal $1-46)$

[19] Wibowo, 2013. Perilaku dalam Organisasi. Raja Grafindo Persada. Jakarta. (hal 59 - 72)

[20] William L Cron, Marion G Sobol. 1983. The relationship between computerization and performance: a strategy for maximizing the economic benefits of computerization. Journal Information \& management. Volume 6. (hal 171-181) NorthHolland. 